\title{
On the Syntax of Sentential Negation in Yemeni Arabic
}

\author{
Abdulrahman Alqurashi ${ }^{1} \&$ Mukarram Abduljalil ${ }^{1}$ \\ ${ }^{1}$ Department of European Languages \& Literature, King Abdelaziz University, Jeddah, Saudi Arabia \\ Correspondence: Abdulrahman Alqurashi, P.O. BOX 80200, Jeddah 21589, Saudi Arabia. E-mail: \\ aaalqurashi@kau.edu.sa
}

Received: December 26, 2019 Accepted: January 31, 2020 Online Published: February 23, 2020

doi:10.5539/ijel.v10n2p331 URL: https://doi.org/10.5539/ijel.v10n2p331

\begin{abstract}
In this paper we explore the system of negation in modern Arabic dialects with a particular focus on Yemeni Arabic (Raymi dialect). The data observed in this dialect incorporate important and novel facts related to the syntax of sentential negation in Arabic. This includes the distribution of negation patterns and the interaction between negation and negative polarity items, which challenges the two widely adopted analyses for sentential negation in Arabic: The Spec-NegP analysis and the discontinuous Neg analysis. In this paper we argue that neither analysis can provide an adequate account of Raymi Arabic facts. Instead, a more recent analysis, the Spilt-Neg analysis, can accommodate them. In addition, in the study we provide empirical evidence in support of the Higher-Neg analysis, wherein Neg is projected higher than $\mathrm{T}$ in the derivation.
\end{abstract}

Keywords: Arabic dialects, discontinuous negation, negative polarity items, non-discontinuous negation, Raymi dialect, sentential negation, Yemeni Arabic

\section{Introduction}

The syntax of negation in Arabic is as extremely diverse as the varieties of the language themselves. Negation can be expressed in various ways that use different patterns across the varieties of Arabic (note 1). Negative constructions in these varieties range from those containing a single negative marker, such as Modern Standard Arabic (henceforth, MSA) as in (1), Gulf Arabic, Hijazi Arabic and Syrian Arabic, to those containing two negative markers (bipartite negation), such as Moroccan Arabic as in (2) (note 2), Egyptian Arabic, Palestinian Arabic, Yemeni Arabic (henceforth, YA) and so forth.

(1) a. maa kataba Ali-un r-risala-t-a.

NEG wrote.3.M.SG Ali-NOM DEF-letter-3.F.SG-ACC

'Ali did not write the letter.'

b. maa Ali-un fi d-daar-i.

NEG Ali-NOM in DEF-house-GEN

'Ali is not in the house.'

(2)
a. Omar ma-ktəb-̌̌
b. Omar ma-ši mriD
Omar NEG-NEG sick
'Omar is not sick.'

lə-bra

(Moroccan Arabic)

Omar NEG-wrote.3.M.SG-NEG DEF-letter

'Omar did not write the letter.'

(Benmamoun, 2000, p. 7)

Most modern Arabic varieties that have bipartite negation use the negative markers $m a(a)$ and $-\check{s}(i)$ (note 3 ), which can be realised discontinuously or non-discontinuously. In the context of verbal predicates, sentential negation is realised by the discontinuous negative elements $m a-V-\check{s}(i)$, where $m a$ - appears as a proclitic and $-\check{s}$ as an enclitic as in (2a) above and (3) below. In the context of non-verbal predicates, sentential negation is realised by the non-discontinuous negative elements $m a-\check{s} i$ or by their variants $m i-\check{s}$ and $m u-\check{s}$ as in (2b) above and (4) below. 
(3)

a. ma-rafaStə-̌s

(Egyptian Arabic)

NEG-raised.1.SG-NEG hand-my

'I did not raise my hand.'

(Brustad, 2000, p. 284)

b. l-walad ma-Para-(̌)

1-kteeb

(Lebanese Arabic)

DEF-boy NEG-read.3.M.SG-(NEG) DEF-book

'The boy did not read the letter.'

(Aoun et al., 2010, p. 96)

c. 1-walad ma-nami-š

(Jordanian Arabic) (note 4)

DEF-boy NEG-slept.3.M.SG-NEG

'The boy did not sleep.'

(Al-Momani, 2011, p. 484)

d. ma-Patiina-hum-š

haqqana s-syarah

(YA-Adani dialect)

NEG-sgave.3.M.SG-3.M.PL-NEG our DEF-car

'We did not give them our car.'

(Mansoor, 2012, p. 55)

(4) a. huwa miš Hna

(Egyptian Arabic)

he NEG here

(Brustad, 2000, p. 283)

'He is not here.'

(Lebanese Arabic)

b. huwwa miš Hina

he NEG here

'He is not here.'

(Aoun et al., 2010, p. 97)

c. huu miš fi l-bayt

(Jordanian Arabic)

he NEG in DEF-house

(Al-Momani, 2011, p. 484)

'He is not at home.'

(YA/Adani dialect)

d. al-bayt muš kabiir

DEF-house NEG big

'The house is not big.'

(Mansoor, 2012, p. 39)

These are almost the negation paradigms observed in many modern Arabic varieties. However, we have come across interesting data from a dialect spoken in Yemen, known as Raymi dialect (note 5), in which the negation paradigm is somehow different. Consider the following examples:

(5) a. maa-katab-ši Ali r-risalah.

(YA/Raymi dialect)

NEG-wrote.3.M.SG-NEG Ali DEF-letter

b. maa-ši katab Ali r-risalah.

NEG-NEG wrote.3.M.SG Ali DEF-letter

'Ali did not write the letter.'

(6) a. maa-huu-ši bi-lbayt.

NEG-he-NEG in the house

b. maa-ši huu bi-lbiyat.

NEG-NEG he in the house

'He is not in the house.'

Contrary to the negation patterns observed in most other modern Arabic varieties, YA (Raymi dialect) employs both the discontinuous negative elements $m a a-\mathrm{x}-\check{s} i$ and the non-discontinuous negative elements $m a a-s ̌ i$ to negate sentences containing verbal predicates (5) and non-verbal predicates (6). This raises the question of whether or not previous analyses of negation in modern Arabic dialects can accommodate these data. Thus, this paper is an attempt to explore the syntax of negation in YA with particular reference to Raymi dialect, with the aim of providing a thorough description of its properties and a preliminary analysis within minimalist syntax.

The remainder of this paper is structured as follows. In section 2, we investigate the properties of the negative 
construction maa...ši in YA, focusing on Raymi dialect, before considering the equivalent constructions in other varieties of Arabic. In section 3, we look at the previous analyses of negation in Arabic to determine whether or not they can accommodate the facts related to negation in YA (Raymi dialect). We then, in section 4, discuss the categorial and functional status of $-s i$ to determine its position in the clausal structure. In section 5 , we provide a preliminary analysis along the lines of Soltan's $(2011,2014)$ Spilt-Neg analysis. Finally, we conclude the paper in section 6 .

\section{The Data}

\subsection{Negation in Raymi Dialect}

Although few studies have been conducted on negation in YA (see, e.g., Mansoor, 2012; Simeone-Senelle, 1996; Vanhove, 1996), to the best of our knowledge, none have been conducted on the syntax of negation in Raymi dialect (note 6). Negation in this dialect is expressed by either the discontinuous negative form maa ... ši or the non-discontinuous negative form maa-ši $i$, which can both be used to negate sentences containing verbal, nominal, adjectival and prepositional predicates as examples (7-10) illustrate, respectively.

(7) a. maa-šik-ši NEG-want.1.SG-NEG gada. lunch

b. maa-ši šik NEG-NEG want.1.SG lunch

'I don't want lunch.'

(8) a. maa-hum-ši Tullaab.

NEG-they-NEG students

b. maa-ši Hum Tullaab.

NEG-NEG They students

'They are not students.'

(9) a. maa-ni-ši mariiD.

NEG-1.SG-NEG ill

b. maa-ši ana mariiD.

NEG-NEG I ill

'I am not ill surely.'

(10) a. maa-hi-ši bi-suuq.

NEG-3.F.SG-NEG in the market

b. maa-ši hi bi-suuq.

NEG-NEG she in the market

'She is not in the market.' gada.
(YA-Raymi dialect) 
c. wa-allah maa ana mariiD ši

by-ALLAH NEG I ill NEG

'I swear by ALLAH, I am not ill surely.'

d. wa-allah maa $\mathrm{Hi}$ bi-suuq ši

by-ALLAH NEG she in the market NEG

'I swear by ALLAH, she is not in the market.'

Like other Arabic varieties, the negative elements maa and $̌ i$ occur in present, past and future tense sentences in both VS and SV orders. Consider the following:

(12)
a. Saleh maa-šaa-ši
gada.

(YA-Raymi dialect)

Saleh NEG-want.1.SG-NEG lunch

b. maa-ši šaa Saleh gada.

NEG-NEG want.1.SG Saleh lunch

'Saleh does not want lunch.'

(13) a. Saleh maa-atta-ši.

Saleh NEG-came.3.M.SG-NEG

b. maa-ši atta Saleh.

NEG-NEG came.3.M.SG Saleh

'Saleh did not come.'
a. Salwa maa-it-siir-ši
S-suuq.
Salwa NEG-FUT-go.3.F.SG-NEG DEF-market
b. maa-ši it-siir
Salwa s-suuq.
NEG-NEG FUT-go.3.F.SG Salwa DEF-market

'Salwa will not go to the market.'

Clearly, neither tense nor agreement affects the negative particles maa and $\check{s} i$.

In the context of yes/no questions, maa and ši also appear. It is common in Raimi dialect, as in other Yemeni dialects, that yes/no questions are constructed as declarative sentences with rising intonation at the end. Consider the following examples:
a. maa-šimihk-ši
1-qamar ams alaši

(YA-Raymi dialect)

NEG-saw.2.SG-NEG moon last night

'Didn't you see the moon last night?'

b. laa, maa-šimihk-oh ̌̌i

NEG NEG-saw.1.SG -3.M.SG NEG

'No, I did not see it.'

\subsection{Maa...ši in Other Dialects and Varieties of Arabic}

Watson (1993, pp. 121, 226) reported some examples from YA (SanSani dialect) where the non-discontinuous negative elements $m a a-s ̌ i$ are used in two cases: first, to provide a negative answer to yes/no questions as in (16), and second, in elliptical contexts as in (17).

(16)
a. zawji-šs
yi-safir
husband-3.F.SG
travel.3.M.SG

Pal-yaman?

(YA-SanSani dialect)

'Will your husband travel to Yemen?'

b. maa-ši, (maa-ysaafur-š

DEF-Yemen

NEG-NEG NEG-travel.3.M.SG- NEG

Pal-yaman.)

'No, he will not travel to Yemen.' 


$$
\begin{array}{llllll}
\text { bih } & \text { naas } & \text { yšillu } & \text { 1-jild } & \text { u-naas } & \text { maa-ši. } \\
\text { there } & \text { people } & \text { take off.3.PL } & \text { DEF-skin } & \text { and-people } & \text { NEG-NEG }
\end{array}
$$

'There are people who take off the skin and some people who don't. (Watson, 1993, pp. 121, 226)

This is very much the situation in a southern dialect in Saudi Arabia (henceforth, SA) known as Zahran dialect. The non-discontinuous negative elements maa-ši appear in negative answers to yes/no questions. Interestingly, ši can appear in positive answers to yes/no questions as well. Consider the following examples:
a. maa-ši rajjaal fii-lbayt?
(SA/Zahran dialect)
NEG-NEG man in the house
'Isn't there any man in the house?'
b. maa-ši had.
NEG-NEG one
'No, there is no one at all.'
c. ši wahid.
there one
'There is one.'

Note that the non-discontinuous negative elements maa-ši are also attested in this dialect to deny the existence of someone or something, as in (19).

(19) a. maa-ši rajjaal fii-lbayt. (SA/Zahran dialect) NEG-NEG man in the house

'There is no man in the house.'

b. maa-ši wala ši / waћid

NEG-NEG even thing / one

'There is nothing/no one.'

In addition, Mansoor (2012, p. 39) provided examples from YA (Abyani dialect) where the non-discontinuous negative elements $m a a-s ̌ i$ appear with non-verbal predicates, specifically to negate prepositional predicates.

$$
\begin{aligned}
& \text { maa-ši maS-hum hata Riyal } \\
& \text { NEG-NEG with-3.M.PL even Riyal } \\
& \text { 'They don't have even a riyal.' }
\end{aligned}
$$

Vanhove (1996, pp. 4, 7) explored negation in YA (Yaafici dialect) and provided examples where the non-discontinuous negative elements $m a a-s ̌ i$ are used to negate sentences with verbal predicates and non-verbal predicates, as shown below (note 8 ).

maa-ši axalli hadd

(YA/YaafiYi dialect)

NEG-NEG leave.1.SG nobody

'I shall let nobody.'

$$
\begin{array}{lllll}
\text { qulak } & \text { maa-ši } & \text { Gaaši } & \text { Pidduuk-haa } & \text { 1-masaakiin } \\
\text { said.1.SG } & \text { NEG-NEG } & \text { dinner } & \text { gave.1.SG-3.F.SG DEF-poor.PL }
\end{array}
$$

'I said: There is no dinner, I gave it to the poor people.'

$$
\begin{array}{ll}
\text { maaši huu bani-š } \\
\text { NEG } & \text { he } \quad \text { son-2.F.SG }
\end{array}
$$

'He is not your son.'

$$
\text { (Vanhove, 1996, pp. 4, 7) }
$$

Vanhove (1996, p. 4) noted that ši is used in association with maa in the Yaafiৎ dialect to serve specific purposes, among which is denying existence. She termed maaši 'the negative marker of existence'. Furthermore, she noted that the negative elements maa-ši in all the examples she recorded are placed either before an indeterminate noun (23) or after a determinate noun (24) or a demonstrative pronoun (25). 
(23)
wuSul
u r-raas
maa-ši

arrived.3.M.SG and DEF-head NEG-NEG

'He arrived and there was no head.'

(24) un dii maa-ši

and this NEG-NEG

'And there was nothing.'

(Vanhove, 1996, p. 4)

Note that in SanSani, Abyani and Yaafíi dialects, the negative particles maa and ši are realised only as non-discontinuous elements, in contrast to the data from Raymi dialect shown earlier. However, Vanhove (1996, p. 2) observed that maa-ši can occur discontinuously in Yaafißi dialects when the non-clitic ši means 'nothing', as illustrated by the following example.

(26)

$$
\begin{array}{ll}
\text { maa } & \text { Pasuuk ši } \\
\text { NEG } & \text { found-1.SG nothing }
\end{array}
$$

'I did not find anything.'

(Vanhove, 1996, p. 2)

The negative elements maa-š $i$ are also attested in other Arabic varieties such as Moroccan Arabic, in which sentential negation is marked with both the non-discontinuous form $m a-s ̌ s$ (with short vowels) in the context of non-verbal predicates and the discontinuous form $m a-\mathrm{v}-5 \mathrm{~s} i$ in the context of verbal predicates, as noted in (2). This is different from the case in YA (Raymi dialect), as discussed earlier. However, Ouhalla (2002, p. 304) reported some examples of negative clefts in Moroccan Arabic, in which the non-discontinuous form $m a-s ̌ i$ is used to negate sentences containing verbal predicates such as the following:

$$
\begin{array}{llll}
\text { ma-ši } & \text { qrat } & \text { Nadia } & \text { l-ktab. } \\
\text { NEG-VAR } & \text { read } & \text { Nadia } & \text { the-book }
\end{array}
$$

'It is not the case that Nadia read the book.'

* 'Nadia did not read the book.'

Note that the interpretation here is semantically different. The example in (27) does not negate a statement but corrects it by letting the listener suppose the unsaid, that Nadia bought, borrowed, threw or wrote the book. However, similar examples of such readings are not found in the Yemeni dialect of Riamah.

As for MSA, the equivalent construction would be the one introduced by a single negative particle maa, which can be used to negate in a wide range of contexts. Thus, it can negate sentences with verbal predicates in the past and present (habitual only) tenses, as shown in (28a) and (28b), respectively. It can also negate sentences with non-verbal predicates, namely nominal as in (27c), prepositional as in (28d) and adjectival phrases as in (28e).
a. maa kataba
Ali-un r-risala-t-a.
NEG wrote.3.M.SG Ali-NOM DEF-letter-3.F.SG-ACC
'Ali did not write the letter.'
b. maa ya?kulu Ali-un Pilla šay?-an yasiir-an
NEG said.3.M.SG Ali-NOM except thing-ACC little-ACC
'Ali eats nothing, but little / Ali eats only very little food.'
c. maa Ali-un muSalim-un.
NEG Ali-NOM teacher-NOM
'Ali is not a teacher.'
d. maa Ali-un fi d-daar-i.
NEG Ali-NOM in DEF-house-GEN
'Ali is not in the house.'
e. maa Ali-un Tawiil-un.
NEG Ali-NOM tall-NOM
'Ali is not tall.

(MSA) 
Negative constructions that use the single negative marker maa or its variant muи are also attested in many Arabic varieties such as Saudi Arabic, Syrian Arabic, Kuwaiti Arabic and almost all the dialects spoken in the Arabian Gulf Region. To illustrate this, some examples are given below.

$$
\begin{array}{llll}
\text { a. } & \text { maa } & \text { katab Ali } & \text { r-risala-h } \\
\text { NEG } & \text { wrote.3.M.SG Ali } & \text { DEF-letter-3.F.SG }
\end{array}
$$

(Saudi Arabic)

'Ali did not write the letter.'

b. al-bayt muu/maa-hu kabiir

DEF-house NEG/NEG-3.M.SG big

'The house is not big.'

(30) a. maa habbiit-a

(Syrian Arabic)

NEG loved.1.SG-3.F.SG

'I did not love her.'

b. al-bayt muu kibiir

DEF-house NEG big

'The house is not big.'

(Based on Brustad, 2000)

(31) a. maa bityi

(Kuwaiti Arabic)

NEG will.come.3.F.SG

'She won't come.'

b. s-sayara-h muu/maa-hi kabiir-h

DEF-car-3.F.SG NEG / NEG-3.F.SG big-3.F.SG

'The house is not big.'

(Based on Brustad, 2000)

The preceding discussion is summarised in Table 1, which focuses only on the use of the negative marker maa and

\begin{tabular}{|c|c|c|c|}
\hline \multicolumn{2}{|l|}{ Variety/Dialect } & \multirow{3}{*}{$\begin{array}{l}\text { Verbal Predicates } \\
m a a+\mathrm{V} \\
m a a+\mathrm{V}\end{array}$} & \multirow{3}{*}{$\begin{array}{l}\text { Non-verbal Predicates } \\
m a a+{ }_{\mathrm{DP} / \mathrm{Adj} / \mathrm{PP}} \\
m a a s ̌ i\end{array}$} \\
\hline \multicolumn{2}{|c|}{ Modern Standard Arabic } & & \\
\hline \multirow[t]{2}{*}{ Saudi Arabic } & Southern dialects & & \\
\hline & Other dialects & $m a a+\mathrm{V}$ & $m u{ }^{+}{ }_{\mathrm{DP} / \mathrm{Adj} / \mathrm{PP}}$ \\
\hline \multirow[t]{7}{*}{ Yemeni Arabic } & Raymi dialect & maa ši $+_{\mathrm{V}}$ & $m a a+\check{s} i+{ }_{\mathrm{DP} / \mathrm{Adj} P / P P}$ \\
\hline & & $m a a++_{\mathrm{V}}+\check{s} i$ & $m a a_{\mathrm{DP} / \mathrm{Adjp} / \mathrm{PP}}+\check{s} i$ \\
\hline & & $m a a+{ }_{\mathrm{V}}+{ }_{\mathrm{XP}}+\check{s i}($ oath context) & \\
\hline & YaafiYi dialect & maaši $_{+}$ & $m a a s ̌ i+{ }_{\mathrm{DP}, \mathrm{AdjP}, \mathrm{PP}}$ \\
\hline & Sanৎani & $m a a+v-\check{s}$ & 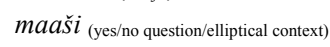 \\
\hline & Abyani dialect & $m i \check{s}+\mathrm{V}$ & $m a a s ̌ i ~ / m i s ̌ s+{ }_{\mathrm{DP} / \mathrm{Adjp} / \mathrm{PP}}$ \\
\hline & Adeni dialect & $m a a+\mathrm{V}-\check{s}$ & Muš \\
\hline \multirow{3}{*}{\multicolumn{2}{|c|}{$\begin{array}{l}\text { Moroccan Arabic } \\
\text { Egyptian Arabic }\end{array}$}} & $m a+\mathrm{V}-\check{s}(i)$ & $m a s ̌ i+{ }_{\mathrm{DP} / \mathrm{AdjP} / \mathrm{PP}}$ \\
\hline & & $m a+\mathrm{V}-\check{s}(i)$ & $m i{ }^{2}+{ }_{\mathrm{DP} / \mathrm{AdjP} / \mathrm{PP}}$ \\
\hline & & $m a+\mathrm{v}-(\widetilde{s})$ (with some NPIs) & \\
\hline \multicolumn{2}{|l|}{ Lebanese Arabic } & $m a a+\mathrm{V}-(\widetilde{s})$ & $m i s ̌+{ }_{\mathrm{DP} / \mathrm{Adj} P / \mathrm{PP}}$ \\
\hline \multicolumn{2}{|l|}{ Syrian Arabic } & $m a a+\mathrm{V}$ & $m u и+{ }_{\mathrm{DP} / \mathrm{Adj} / \mathrm{PP}}$ \\
\hline \multicolumn{2}{|c|}{ Jordanian Arabic } & $m a a+\mathrm{v}-\check{s} / m a a+\mathrm{v}$ & $m i \check{s}+{ }_{\mathrm{DP} / \mathrm{Adj} P / P P}$ \\
\hline \multicolumn{2}{|c|}{ Palestinian Arabic } & $m a a+\mathrm{v}-(i) \check{s} / m a a+\mathrm{v}$ & $m i \check{s}+{ }_{\mathrm{DP} / \mathrm{Adj} P / P P}$ \\
\hline \multicolumn{2}{|c|}{ Kuwaiti Arabic + varieties in the Arabian Gulf Regions } & $\mathrm{maa}_{\mathrm{V}}$ & $m u и+{ }_{\mathrm{DP} / \mathrm{AdjP} / \mathrm{PP}}$ \\
\hline
\end{tabular}
its variants maaši, ma-ši, ma-š, mi-šs, muš, muи and so forth in the varieties of Arabic.

Table 1. Patterns of negation in Arabic

To sum up, in YA (Raymi dialect) the negative elements maa-ši are used continuously and discontinuously to negate all sorts of sentences. Furthermore, they are realised as two negative elements and not as a single complex form consisting of two parts: maa $+-\check{s} i$. Moreover, the second negative marker $-\check{s} i$ can appear in pre-predicate position and in post-predicate position. The question that arises here is how these facts related to negation in YA can fit within previous analyses of negation in Arabic. Let us now consider these analyses to determine whether they can accommodate these facts. 


\section{Previous Analyses}

One of the earliest analyses proposed to explain sentential negation in modern Arabic dialects along the lines of Chomsky's (1995) minimalist program is Benmamoun's (2000), which has since been widely adopted (see, e.g., Aoun et al., 2010). He argued that the two-part negative marker is a complex head generated in Neg, which is located between TP and the predicate as in (32).

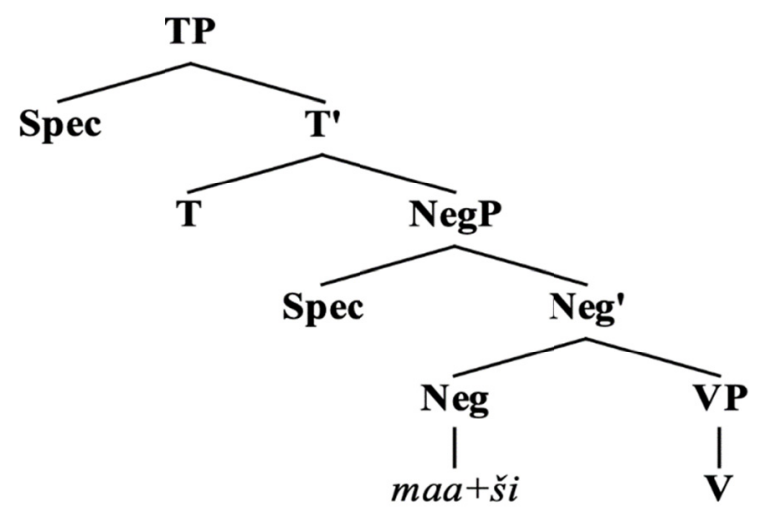

Benmamoun (2000, p. 76)

Benmamoun's (2000) assumption is that maa-ši forms a single unit made up of a proclitic and enclitic and that the distribution of sentential negation depends on whether some lexical head has moved to the head position of NegP or through it. Thus, if movement occurs, negation is realised with the circumfixal pattern (discontinuous maa...ši). On the other hand, if movement does not occur, the complex negative head is realised as one single non-discontinuous element $m a a+\check{s} i$. In fact, this analysis depends to a large extent upon the distinction he made between past tense and non-past tense with respect to the features they carry. He proposed, based on a number of interesting facts he observed in MSA and Arabic dialects, that past tense in Arabic is specified for both a categorial $[+\mathrm{D}]$ and $[+\mathrm{V}]$ feature, whereas present tense is specified only for a categorial $[+\mathrm{D}]$ feature. The $[+\mathrm{D}]$ triggers the movement of the subject to the specifier position of TP (i.e., EPP feature), and the $[+\mathrm{V}]$ triggers the movement of $\mathrm{V}$ to $\mathrm{T}$. Thus, when the $[+\mathrm{V}]$ feature on $\mathrm{T}$ in (31) triggers the movement of the past verb, which is placed under NegP, this movement will apply in a successive-cyclic fashion. This means that the verb moves first from V to Neg and then from Neg to T in accordance with the Head Movement Constraint (note 9) as shown in (33) below.

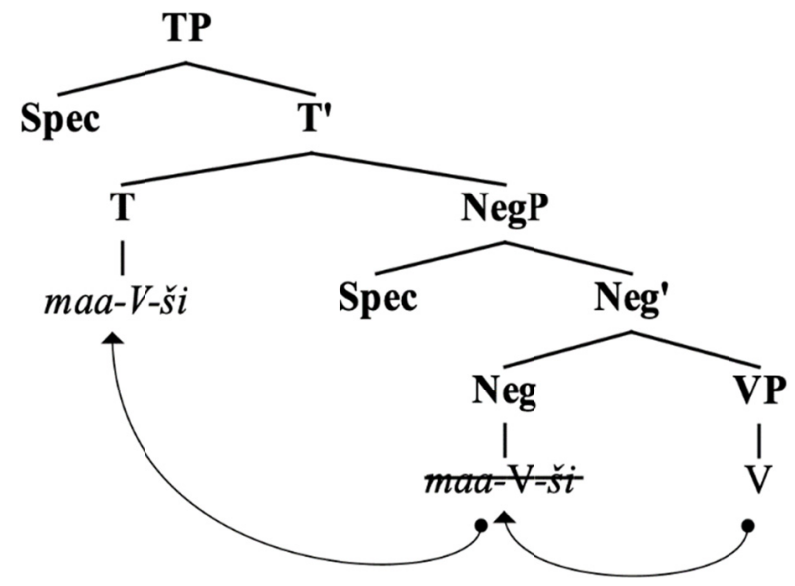

However, it is not clear how this approach can accommodate the aforementioned facts concerning the distribution of sentential negation in Raymi dialect. First, recall that this dialect employs both forms of negation-the discontinuous maa...šs and the non-discontinuous maa-ši - to negate all sort of sentences, including ones with past and non-past tense. Benmamoun (2000) claimed that verbs in past tense sentences always merge with the negative element maa ...ši on its way to T but not in present tense sentences. Furthermore, Aoun et al. (2010), who built on Benmamoun's analysis, claimed that there are no dialects of Arabic where this is not the case. To this general claim, however, YA is one exception; otherwise sentences such as (5b) and (7a) above would be unacceptable (note 10). In fact, such examples clearly cast doubt on Benmamoun's analysis in $(32,33)$ and on his general distinction between past tense and non-past tense in Arabic with respect to movement. Second, recall also 
that in Raymi dialect the first particle maa always precedes the predicate, whereas the second particle ši appears in different positions. This suggests that the negatives maa and $\check{s} i$ are two independent markers occupying different positions and not a single complex form consisting of two parts (the prefix maa- and the suffix -ši) generated in $\mathrm{Neg}^{\circ}$. Finally, Benmamoun's analysis faces problems accounting for negation in future tense sentences in some Arabic dialects. In fact, this issue was first observed by Soltan (2007, p. 185) in Egyptian Arabic, where the negative marker miš precedes the future tense marker as in (34) below. The situation in Raymi dialect is slightly different, as the examples in (35) illustrate. We will return to this later.
(34) xalid
miš (f-əl-gaalib) ћa-yə-?ra
1-kitaab
(Egyptian Arabic)
Khalid NEG (probably)
FUT-IMPER.read.3.M.SG DEF-book
'Khalid probably won't read the book.'
a. Saleh Maa ša-siir ši s-suuq.
Saleh NEG FUT-go.3.M.SG NEG DEF-market
b. maa ši ša-siir Saleћ s-suuq.
NEG NEG FUT-go.3.M.SG Saleh DEF-market
'Saleh will not go to the market.'

Given that tense markers are normally placed under T, then the NegP is expected to occupy a position higher than TP, otherwise the derivation will crash. A similar issue has been noted in Moroccan, Levantine and Gulf Arabic (Benmamoun et al., 2013), where the negative morphemes are realised on the future modal and not on the main verb, as the examples in (36-38) illustrate, respectively.
a. Mohammed ma-ġadi-š y-ąqəl Slik
Mohammed NEG-FUT-NEG remember.3.M.SG on.you
'Mohammed will not remember you.'
b. *Mohammed gadi ma-y-ąqəl-š
Clik
Mohammed FUT NEG-remember.3.M.SG-NEG on.you

(Moroccan Arabic)
a. Pana ma-rah ?axud-ha
I NEG-FUT take.1.M.SG.it
'I will not take it.'
b. *2anarah maa-?axud-ha
I FUT NEG-take.1.M.SG.it

(38)
a.
ma-raћ Paguul lak
NEG-FUT say.1.M.SG to.you me who
'I will not tell you who I am.'
b. *rah maa-Paguul lak Pana man
FUT NEG-say.1.M.SG to.you me who

(Based on Benmamoun et al., 2013, p. 97)

(Benmamoun et al., 2013, p. 91)

(Moroccan Arabic)

(Levantine Arabic)

It can be inferred from the preceding discussion that Benmamoun's (2000) analysis, referred to in the literature as Low-Neg Analysis, cannot account for all the facts related to sentential negation in Modern Arabic varieties. There is, however, an alternative analysis to Low-Neg Analysis proposed by Soltan (2007), where NegP is located in a position higher than a TP, along the lines suggested by Fassi Fehri (1993) and Shlonsky (1997). This analysis is referred to as High-Neg Analysis (Soltan, 2011) and is sketched in (39) below. Ample empirical evidence from different Arabic varieties supports High-Neg Analysis over Low-Neg Analysis (see Benmamoun et al., 2013; Soltan, 2011 for more information). 
(39)

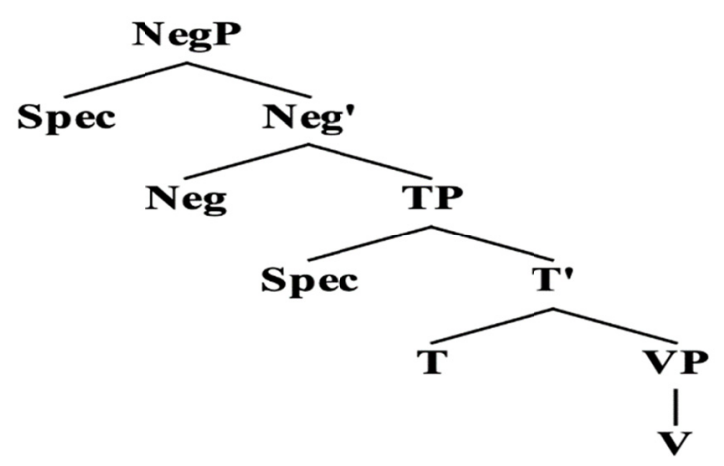

\section{More on the Negative Element $\breve{s i}$}

There is no doubt that maa is a negative marker because it is widely used in almost all Arabic varieties/dialects. However, researchers have called into question the syntactic and semantic nature of the particle $\check{s} i$, which appears in some varieties/dialects and is absent from others. It seems that ši is derived from the word šay? 'thing' in MSA, as observed by Benmamoun (2000) and Ouhalla (2002). However, the grammatical category and function of šay' in MSA differs from those of $̌ i$ in the Arabic varieties/dialects. It is a noun and can have different syntactic and semantic functions. Consider the following examples from MSA.

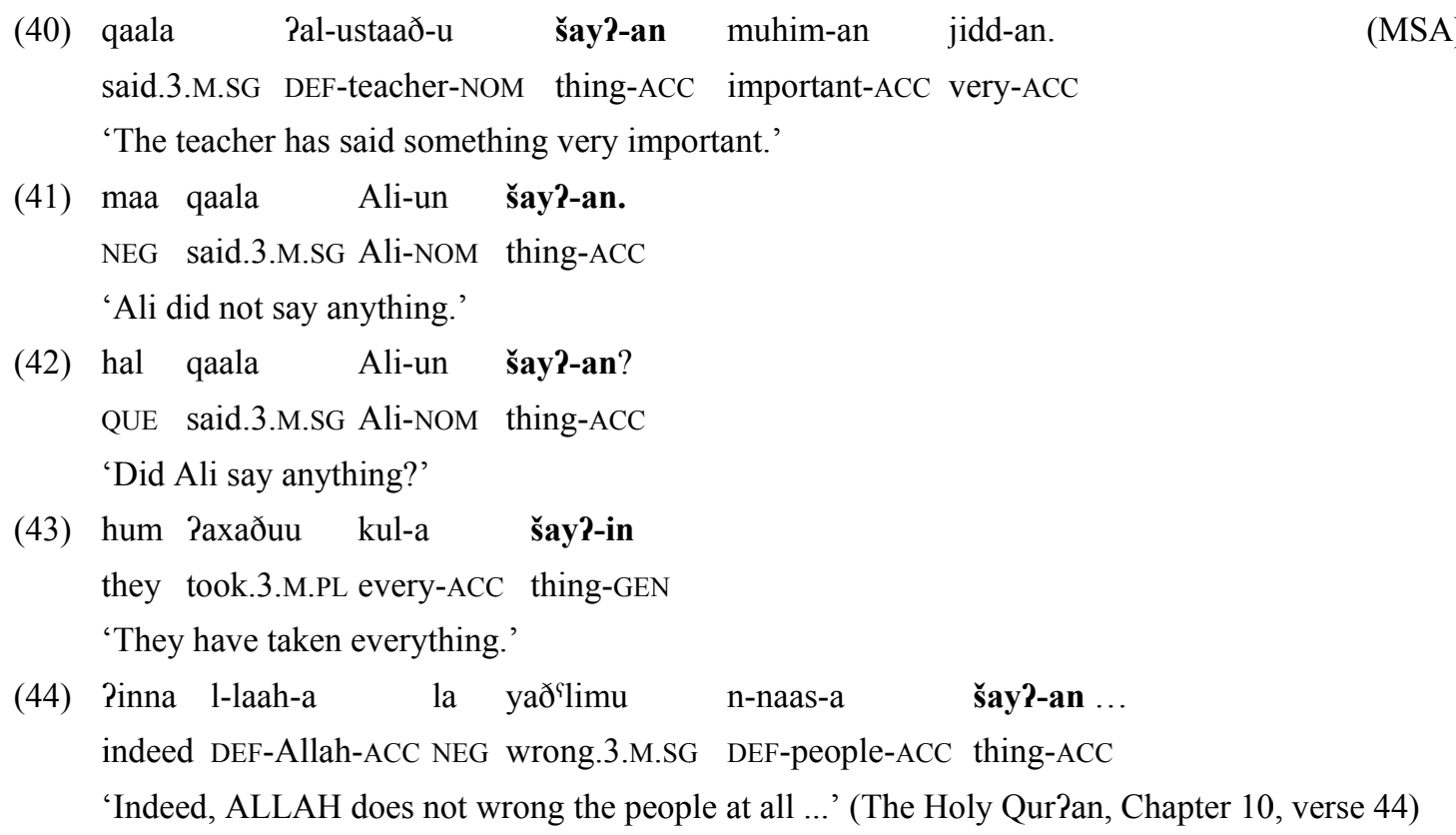

The noun šay?an functions syntactically as a direct object in (40-42) but not in (44). According to traditional Arab grammarians (see, e.g., Darwish, 2002), šay?an in (44) has two possible functions: either a cognate/accusative object (note 11) or a second object. According to Badawi, Carter and Gully (2004, p. 147), the cognate/accusative object in Arabic 'can be replaced by an explanatory term,' which is not related to the verb morphologically. Thus, the cognate object in (44), which might be recognised as J'ulman, is assumed to be elided and replaced by šay?an, which gives more emphasis to the verb. On the other hand, šay?an can function as a second object if the verb уад limu is interpreted as a ditransitive verb denoting the meaning of 'take away from/deprive of' (note 12). Semantically, šay?an can function as an existential quantifier as in (40), as a negative polarity item (henceforth, NPI) as in $(41,42,44)$ or as a part of a universal quantifier phrase as in (43). The counterparts of these examples in YA (Raymi dialect) are shown below. Note that the word haajah, which also means 'thing', can be substituted for $̌ s i$ in all the examples.
(45) qaal Pal-ustaad ši / haajah mihim / mihimh. (YA/Raymi dialect)
said.3.M.SG DEF-teacher thing important
'The teacher has said something important.' 
(46) maa-ši qaal Ali ši / haajah

NEG-NEG said.3.M.SG Ali thing

'Ali did not say anything.'

(47) qaal Ali ši / haajah?

said.3.M.SG Ali thing

'Did Ali say anything?'

(48) Hum bazzu kul ši / haajah.

They took.3.M.PL every thing

'They have taken everything.'

(49) Pal-laah maa yað‘lim n-naas ši.

DEF-Allah NEG wrong.3.M.SG DEF-people thing

'ALLAH does not wrong the people at all.'

In some other varieties of Arabic such as Moroccan Arabic, $̌ s i$ can function as a non-specific indefinite, as illustrated in (49) below (Ouhalla, 2002, p. 302).

(50) (Nadia) qrat ši ktab.

(Moroccan Arabic)

(Nadia) read.3.F.SG some book

'Nadia read some book (or other).'

As shown above, šay? or its counterpart $\check{s} i$ can appear in affirmative and negative sentences. Moreover, as discussed in section 2, $\check{s} i$ can be used in some dialects such as the Saudi southern dialects and the Yemeni dialect of Yaafiৎ to confirm or deny the existence of something. However, the question that arises here is what syntactic category $̌ s i$ belongs to. Aoun et al. (2010) pointed out that $\check{s}$ and its cognates $̌ i$, used in vernacular Arabic, seem to have evolved recently from šay? to reinforce the negative marker maa. In addition, Roberts and Roussou (2003), Lucas $(2007,2010)$ and Lucas and Lash (2010) discussed extensively the historical development of $\check{s} i$ and its cognates $\check{s}$ in some Arabic varieties and pointed out that it has undergone historical changes to become a negative marker. However, example (46) is crucial for the answer to this question. The word ši appears twice in (46), which provides sufficient evidence that the first $\check{s} i$ must be treated as a negative marker. Thus, doubts about $̌ s i$ being anything other than a negative marker are removed, at least for Raymi dialect.

Let us now look at the position of $s i$ and how it fits in the analysis. There are three viewpoints in the literature with regard to the position of $\breve{s} i$ : First, ši originates in the specifier position of Neg, which is headed by maa as in (51) (cf. Ouhalla, 1990); second, it is generated with maa under Neg as in (52) (cf. Aoun et al., 2010; Benmamoun, 2000); third, maa and ši originate as two separate heads as in (53) (cf. Soltan, 2011, 2014).

(51)
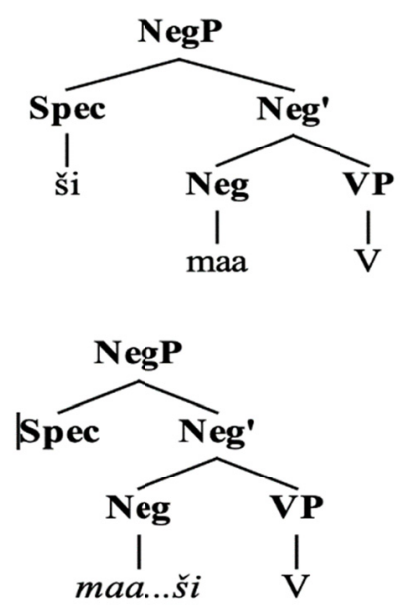
(53)

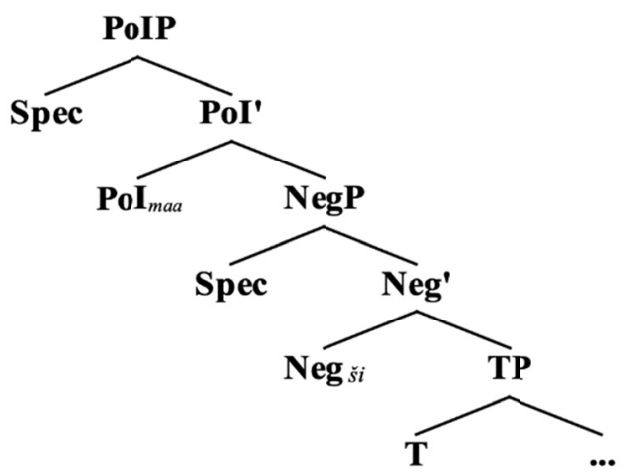

One of the key arguments in favour of the Spec-NegP analysis in (51) comes from the fact that it can easily account for the complementary distribution attested in some Arabic dialects between NPIs and the negative element $-s$. . For example, it has been attested in Moroccan Arabic that NPIs are in complementary distribution with the negative element $-\check{s}$. Consider example (54), where the negative $-\check{s}$ disappears when there is an NPI present.

(54)
a. ma-qrit
hatta ktab
NEG-read.3.F.SG even book
'I didn't read any book.'
b. *ma-qrit-ši hatta ktab
NEG-read.3.F.SG-NEG even book
(Benmamoun, 2006, p. 143)

This can be explained under the $S p e c-N e g P$ analysis if one assumes that an NPI and $-\check{s}$ compete for the specifier position of NegP. This fact is quite difficult to explain under the discontinuous Neg analysis in (52) (note 13).

However, this is not the case in Egyptian Arabic because the negative marker $-\check{s}$ does not disappear when an NPI appears, except in the case of the NPI Sumr 'ever' when it precedes the negative marker maa. The following examples from Soltan (2014, p. 102) illustrate this:
(55)
$\begin{array}{lll}\text { a. Mona } & \text { lissah } & \text { maa-safirit-* }(\breve{\mathbf{s}}) \\ \text { Mona } & \text { yet } & \text { NEG-travelled.3.F.SG-*(NEG) }\end{array}$
b. Mona maa-safirit-(*̌s) lissah
Mona NEG-travelled.3.F.SG-*(NEG) yet
'Mona has not travelled yet.'
(56)
a. Panaa maa-šufti-*(̌) Payy haaga
I NEG-saw.1.M.SG-*(NEG) any thing
'I didn't see anything.'
b. Panaa maa-šufti-*( $\breve{\mathbf{s}})$ haaga xaaliS
I NEG-saw.1.M.SG-*(NEG) thing at all
'I didn't see anything at all.'
a. Gumr-ii
maa-safirt $(*-\check{\mathbf{s}})$
masr
ever-1.SG
NEG-travelled.1.M.SG- $(*$ NEG $)$
E) Egypt
b. maa-safirt-*(ॅ)
masr
Sumr-ii
NEG-travelled.1.M.SG-*(NEG) Egypt
ever-1.SG
'I have never travelled to Egypt.'

Based on these facts, Soltan $(2011,2014)$ argued against the Spec-NegP analysis and proposed the Spilt-Neg analysis in $(52)$ along the lines suggested by Zeijlstra $(2004,2008)$ for negative concord constructions.

Let us now consider the analysis of negation in YA (Raymi dialect) within these approaches. 


\section{The Analysis}

The negation patterns attested in YA (Raymi dialect) suggest that the projection of Neg must be in a position higher than $\mathrm{T}$ in the course of the derivation. Furthermore, the interaction between NPIs and the negative element $-\check{s} i$ in this dialect is quite similar to that observed in Egyptian Arabic, as (58-60) show.

$$
\begin{aligned}
& \text { a. maa-Pada-1-i-*( }(\mathbf{s} \mathbf{i}) \text { hatta riyal } \\
& \text { NEG-gave.3.M.SG-to-2.SG-NEG even Riyal } \\
& \text { b. maa-*(ši) Pada-l-i hatta riyal } \\
& \text { NEG-NEG gave.3.M.SG-to-2.SG even Riyal }
\end{aligned}
$$

$$
\begin{aligned}
& \text { a. Sumr-ii maa-sirk(*-ši) Sanৎa } \\
& \text { ever-1.SG NEG-travelled.1.M.SG Sana'a } \\
& \text { b. maa-sirk-*(ši) Sanᅫa Gumr-ii } \\
& \text { NEG-travelled.1.M.SG NEG Sana'a ever-1.SG } \\
& \text { c. maa-*(si) Sirk Sanfa Sumr-ii } \\
& \text { NEG-NEG travelled.2.M.SG Sana'a ever-1.SG }
\end{aligned}
$$

'I have never travelled to Sana'a.'

$$
\begin{aligned}
& \text { a. Saadu-h maa-ata-*( } \\
& \text { yet-3.M.SG NEG-came.3.M.SG-NEG } \\
& \text { b. Saadu-h maa-*(̌si) Ata } \\
& \text { yet-3.M.SG NEG-NEG came.3.M.SG }
\end{aligned}
$$

These examples demonstrate that NPIs in YA (Raymi dialect) are not always in complementary distribution with the negative element -ši. This suggests that neither the Spec-NegP analysis nor the discontinuous Neg analysis can provide a straightforward account of them. In fact, these examples strengthen the argument in favour of the Spilt-Neg analysis.

As noted above, the distribution of the negation patterns within this dialect does not follow from the contrast observed in many other Arabic dialects between verbal and non - verbal predicates or between past and non-past tense sentences. It seems that there is no restriction on the contexts in which the discontinuous maa...š $i$ and the non-discontinuous maaši patterns occur (note 14). Thus, we argue that a modified version of the Spilt-Neg analysis can account for the distribution of the negation patterns in this dialect.

Soltan $(2011,2014)$ assumed that the negative marker maa is semantically negative, whereas $-s ̌ i$ is formally negative because it developed diachronically from the adverbial usage of the noun šay? 'thing'. Thus, under this analysis maa is treated as a polarity head that originates in Pol and carries the interpretable negative feature [iNeg], whereas $-\check{s} i$ is treated as a negative head that originates in Neg and carries an uninterpretable negative feature [uNeg] (note 15). Soltan (2014) pointed out that the uninterpretable negative feature on Neg is valued via a modified version of Agree (Chomsky, 2000, 2001) between Pol and Neg. Furthermore, he argued that negation patterns are better dealt with as the result of morphological head movement and that $-\check{s}$ can be deleted under certain conditions. He proposed the following head movement algorithm, which applies in the mapping from syntax to morphology (i.e. a post-syntactic rule):

(61) a. In contexts where Neg is adjacent to a hosting head $H, H$ moves to Neg and then to Pol, and the circumfixal maa $-H-\check{s}$ pattern arises.

b. Otherwise, Neg incorporates into Pol, giving rise to the miš - pattern. (Soltan, 2014, p. 104)

A modified version of this algorithm can be adopted to account for the negation system in Raymi dialect. We assume that both steps in (61) are available for the negation patterns in this dialect. Thus, the discontinuous maa...šs pattern (cf. the example in 5a) is derived under step (a) as illustrated in (62), whereas the non-discontinuous maa-ši pattern (cf. the example in 5b) is derived under step (b) as illustrated in (63). 
(62)

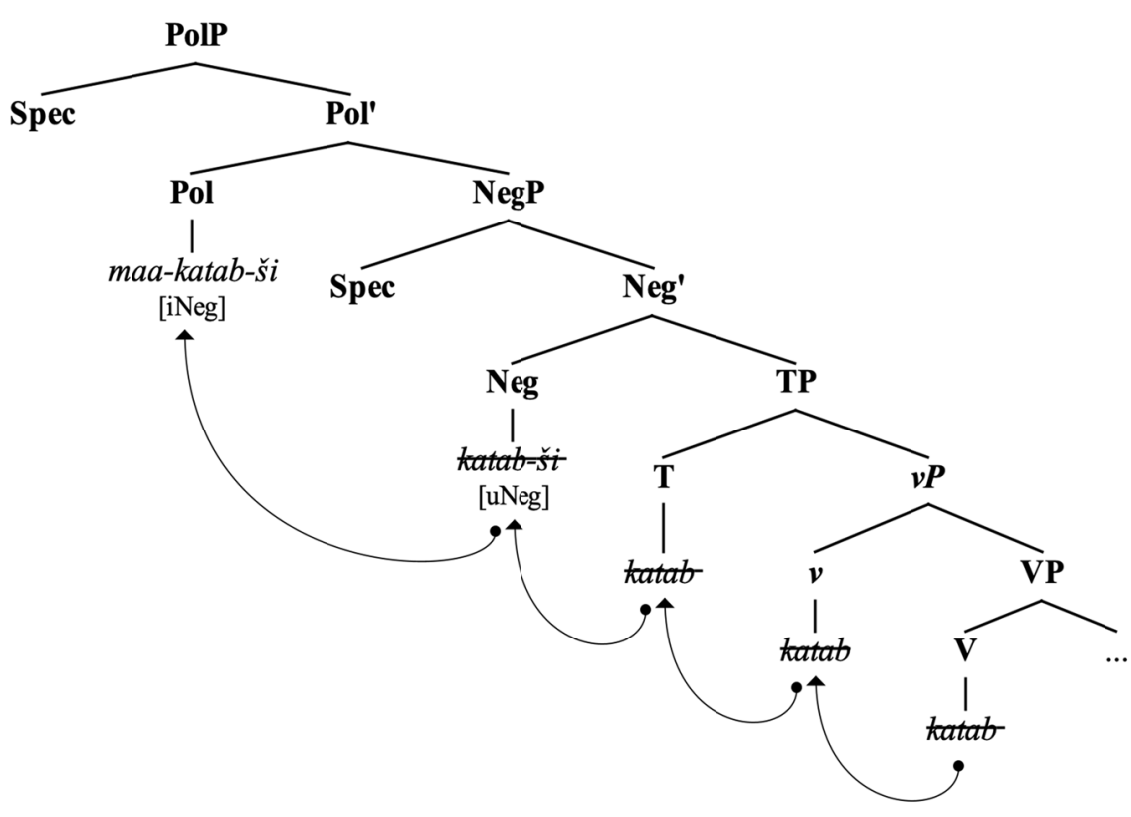

(63)

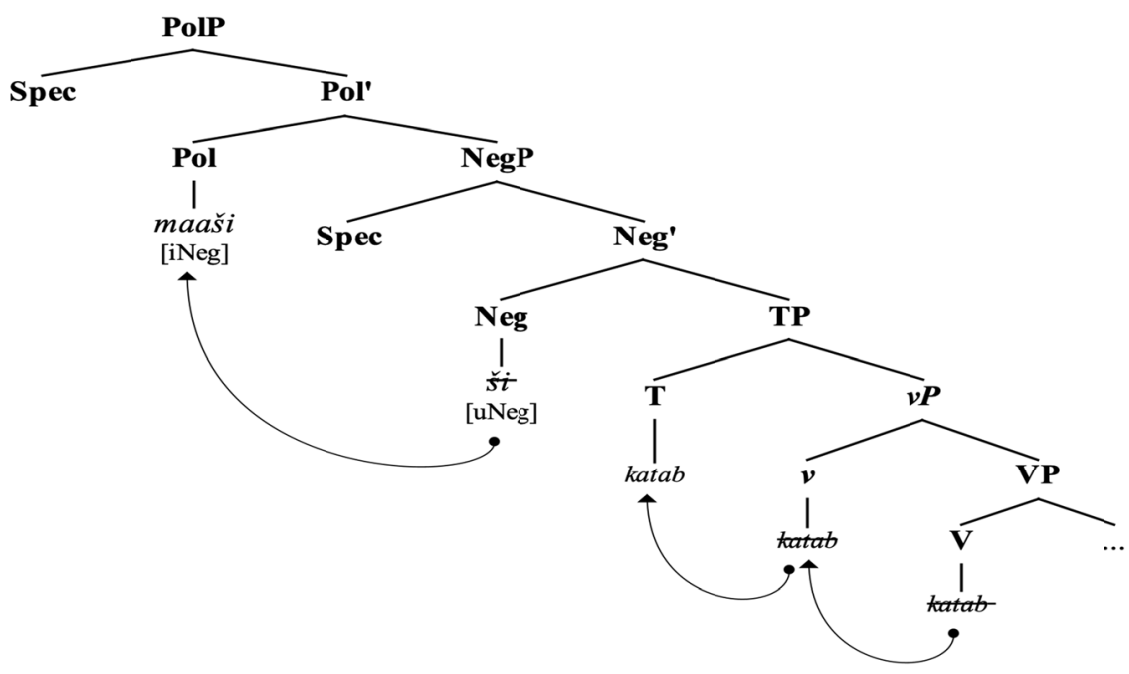

According to Soltan $(2012,2014)$, the Spilt-Neg analysis should allow us to account for the interaction observed in (58-60) above between NPIs and the negative element $-\check{s} i$. He pointed out that the solution to the puzzle of $-\check{s}$ deletion in Cairene Egyptian Arabic has to do with whether or not an NPI is marked for 'formal negativity'. He used two diagnostic tests to distinguish NPIs that are formally marked as negative from those that are not. The first test has to do with whether or not an NPI occurs in non-negative contexts such as interrogative or conditional sentences, and the second has to do with whether or not it occurs as a fragment answer. Let us apply these tests to the NPIs Sumr 'ever' and Saad 'yet' in Raymi dialect. Consider the following examples:

(64)

a. Sumr-ak sirk SanYa?

ever-2.SG travelled.2.M.SG Sana'a

'Have you ever travelled to Sana'a?'

b. Piða Sumr-ak Sirk

Sanৎa laazim tisiir bab 1-yaman

if ever-2.SG travelled.2.M.SG Sana'a must go.2.M.SG gate DEF-Yemen

'If you ever travel to Sana'a, you must visit the gate of Yemen.' 
a. Ali ata *(illa) Saadu-h?

Ali came.3.M.SG or.not yet-3.M.SG

'Has Ali come or not yet?'

$\begin{array}{llll}\text { b. *Piða ata } & \text { Ali } & \text { Saadu-h, laazim tuquul-li } \\ \text { if came.3.M.SG } & \text { Ali } & \text { yet-3.M.SG must } & \text { say.3.M.SG-to.me }\end{array}$

'*If Ali has come yet, you have to tell me.'

(66)

a. Qad Sirk Sanfa min qabl?

have travelled.2.M.SG Sana'a before

'Have you travelled to Sana'a before?'

b. Gumr-ii

ever-1.SG

'Never.'

a. Ali Ata *(illa) Saadu-h

Ali came.3.M.SG or.not yet-3.M.SG

'Has Ali come or not yet?'

b. Gaadu-h

yet-3.M.SG

'Not yet.'

As expected, only the NPI Sumr appears in non-negative contexts such as questions and conditionals (64) and as a fragment answer (66b), whereas the NPI Gaad does not. This suggests that the NPI Gumr is non-negative and that the NPI Gaad is lexically negative.

Based on Soltan's $(2012,2014)$ analysis, the overt realisation of -ši depends on the availability of formal negativity. Thus, -ši disappears only in the presence of a non-negative NPI like Sumr but not in the presence of a negative NPI like Saad. As for the contrast between (59a) and (59b), it can be explained in terms of 'locality'. This means that $-s ̌ i$ disappears only if the NPI Gumr originates within the local domain (i.e. 'close by' as in 59a) but not when it originates outside the local domain (i.e., in a distant position as in 59b) (cf. Soltan, 2014).

\section{Conclusion}

In this paper we discussed negation in Raymi dialect (a variety of YA), which has not been explored prominently before. The aim was to broaden the discussion about the syntax of sentential negation in Arabic. The distribution of the negation patterns observed in this dialect is somehow different from those attested in other Arabic varieties. Both the discontinuous negative pattern $m a a-\mathrm{x}-\check{s} i$ and the non-discontinuous negative pattern $m a a-s ̌ i$ are used to negate sentences containing verbal predicates and non-verbal predicates. Unlike the situation in many Arabic varieties, there is no contrast between verbal and non - verbal predicates or between past and non-past tense sentences with respect to the distribution of the negation patterns in Raymi dialect. In addition, NPIs are not always in complementary distribution with the negative enclitic $-\check{s} i$; it is not always omitted when an NPI occurs. These facts, among others, have posed challenges to the Spec-NegP analysis and the discontinuous Neg analysis, which have been widely adopted for negation in Arabic. We provided some empirical evidence to strengthen the argument in favour of the Higher-Neg analysis, whereby the Neg projects in a position higher than T. Finally, we showed that a morpho-syntactic analysis such as the Spilt-Neg analysis is the best candidate to account for most of the facts related to negation in this dialect.

\section{References}

Al-Momani, I. M. (2011). The syntax of sentential negation in Jordanian Arabic. Theory and Practice in Language Studies, 1(5), 482-496. https://doi.org/10.4304/tpls.1.5.482-496

Al-Shurafa, N. S. (2006). Nominal and verbal negation in Arabic: A minimal limitation. Journal of King Abdulaziz University (JAKU): Arts \& Humanities, 14, 45-60. https://doi.org/10.4197/art.14-1.3

Aoun, J., Choueiri, L., \& Benmamoun, E. (2010). The syntax of Arabic. Cambridge: Cambridge University Press. https://doi.org/10.1017/CBO9780511691775

Ar-raajihi, A. (1988). At-Tabiiq n-naћawii. Beirut: Daar An-nahDah Al-Garabiyya. 
Badawi, E., Carter, M., \& Gully, A. (2004). Modern written Arabic: A comprehensive grammar. London: Routledge.

Benmamoun, E. (1997). Licensing of negative polarity items in Moroccan Arabic. Natural Language and Linguistic Theory, 15(2), 263-287. https://doi.org/10.1023/A:1005727101758

Benmamoun, E. (2000). The feature structure of functional categories: A comparative study of Arabic dialects. USA: Oxford University Press.

Benmamoun, E. (2006). Licensing configurations: The puzzle of head negative polarity items. Linguistic Inquiry, 37(1), 141-149. https://doi.org/10.1162/ling.2006.37.1.141

Benmamoun, E., Abunasser, M., Al-Sabbagh, R., Bidaoui, A., \& Shalash, D. (2013). The location of sentential negation in Arabic varieties. Brill's Journal of Afroasiatic Languages and Linguistics, 5(1), 83-116. https://doi.org/10.1163/18776930-00501003

Brustad, K. (2000). The syntax of spoken Arabic: A comparative study of Moroccan, Egyptian, Syrian and Kuwaiti dialects. Washington, DC: Georgetown University Press.

Chomsky, N. (1995). The minimalist program. Cambridge, MA: The MIT Press.

Chomsky, N. (2000). Minimalist inquiries: The framework. In R. Martin, D. Michaels \& J. Uriagereka (Eds.), Step by step: Essays on minimalist syntax in honor of Howard Lasnik (pp. 89-156). Cambridge, MA: MIT Press.

Chomsky, N. (2001). Derivation by phase. In M. Kenstowicz (Ed.), Ken Hale: A life in language (pp. 1-52). Cambridge, MA: MIT Press.

Darwish, M. A.-D. (2002). ISraab al qur'an wa bayaanih. Beirut: Dar Ibn Kathiir.

Fassi, F. A. (1993). Issues in the structure of Arabic clauses and words. Dordrecht: Kluwer. https://doi.org/10.1007/978-94-017-1986-5

Homeidi, M. A. (2008). Object, absolute. In K. Versteegh et al. (Eds.), Encyclopedia of Arabic language and linguistics (Vol. 3, pp. 455-461). Leiden: Brill.

Lucas, C. (2007). Jespersen's cycle in Arabic and Berber. Transactions of the Philological Society, 105(3), 398431. https://doi.org/10.1111/j.1467-968X.2007.00189.x

Lucas, C. (2010). Negative-š in Palestinian (and Cairene) Arabic: Present and possible past. Brill's Journal of Afroasiatic Languages and Linguistics, 2(1), 165-201. https://doi.org/10.1163/187666310X12688137960623

Lucas, C., \& Lash, E. (2010). Contact as catalyst: The case for Coptic influence in the development of Arabic negation. Journal of Linguistics, 46(2), 379-413. https://doi.org/10.1017/S0022226709990235

Mansoor, J. (2012). The syntax of negation in Yemeni Arabic. Doctoral dissertation, EFL University, Hyderabad.

Ouhalla, J. (1990). Sentential negation, relativised minimality and the aspectual status of auxiliaries. The Linguistic Review, 7(2), 183-231. https://doi.org/10.1515/tlir.1990.7.2.183

Ouhalla, J. (2002). The structure and logical form of negative sentences in Arabic. In J. Ouhalla \& U. Shlonsky (Eds.), Themes in Arabic and Hebrew syntax (pp. 299-320). Dordrecht: Kluwer. https://doi.org/10.1007/978-94-010-0351-3_11

Roberts, I., \& Roussou, A. (2003). Syntactic change: A minimalist approach to grammaticalization. Cambridge: Cambridge University Press. https://doi.org/10.1017/CBO9780511486326

Ryding, K. (2005). A reference grammar of modern standard Arabic. Cambridge: Cambridge University Press. https://doi.org/10.1017/CBO9780511486975

Shlonsky, U. (1997). Clause structure and word order in Hebrew and Arabic: An essay in comparative Semitic syntax. Oxford: Oxford University Press.

Simeone-Senelle, M. C. (1996). Negation in some Arabic dialects of the Tihaamah of the Yemen. Amsterdam Studies in the Theory and History of Linguistic Science Series, 4, 207-222. https://doi.org/10.1075/cilt.141.17sim

Soltan, U. (2007). On format feature licensing in minimalism: Aspects of standard Arabic morphosyntax. Doctoral dissertation, University of Maryland.

Soltan, U. (2011). On issues of Arabic syntax: An essay in syntactic argumentation. Brill's Journal of Afroasiatic Languages and Linguistics, 3(1), 236-280. https://doi.org/10.1163/187666311X562486 
Soltan, U. (2014). Splitting Neg: The morphosyntax of sentential negation in Cairene Egyptian Arabic revisited. Perspectives on Arabic Linguistics, 26, 91-120. https://doi.org/10.1075/sal.2.07sol

Travis, L. (1984). Parameters and effects of word order variation. Doctoral dissertation, MIT.

Vanhove, M. (1996). The negation maaši in a Yaafi 'i dialect (Yemen). In M. Eid \& D. Parkinson (Eds.), Perspectives on Arabic linguistics IX (pp. 195-206). Papers from the Ninth Annual Symposium on Arabic Linguistics. Georgetown University, 10-12 March 1995, Washington. John Benjamins. https://doi.org/10.1075/cilt.141.16van

Watson, J. (1993). A syntax of SanSani Arabic. Wiesbaden: Otto Harrassowitz.

Zanuttini, R. (1997). Negation and clausal structure: A comparative study of Romance languages. Oxford: Oxford University Press.

Zeijlstra, H. (2004). Sentential negation and negative concord. Doctoral dissertation, University of Amsterdam.

Zeijlstra, H. (2008). Negative concord is syntactic agreement. Ms., University of Amsterdam, 5, 113.

\section{Notes}

Note 1. See, e.g., Aoun, Choueiri and Benmamoun (2010), Benmamoun (1996, 2000, 2006), Benmamoun, Abunasser, Al-Sabbagh, Bidaoui and Shalash (2013), Brustad (2000), Fassi Fehri (1993), Ouhalla and Shlonsky (2002), Shlonsky (1997), Soltan (2007, 2011) and Vanhove (1996).

Note 2. An anonymous reviewer has pointed out that $m a-m r i D-s ̌$ is also possible in Moroccan Arabic. The enclitic $-\breve{s}$ is optional with verbal and nominal predicates in some regions in Morocco.

Note 3. Note that the proclitic $m a$ - and the enclitic - $\check{s}$ may sometimes be pronounced in some Arabic dialects as maa- and $-\check{s} i$.

Note 4. The negation system in Palestine Arabic is quite similar to that of Jordanian Arabic. Note that sometimes an optional vowel $(i)$ is inserted before the second negative particle $\breve{s}$ (see Al-Shurafa, 2006; Shlonsky, 1997).

Note 5. The governorate of Raymah is in the middle of the western mountains. It is bordered by the Sana'a governorate to the north and east, by Hudaydah to the west and by the Dhamar governorate to the south. It is administratively divided into six provinces, and the town of Al-Jabeen is the centre of the governorate. Most of the people of Raymah still have some phonetic characteristics of the old dialect of Hamriya, where the sound (q) is dark and the letter $(\mathrm{k})$ is added to the verb of the first and the second person. The area of the province of Raymah is about $2000 \mathrm{~km}^{2}$, and the population is around 600,000 . Raymi dialect is named after the governorate of Raymah, where it is mainly spoken, although it is also spoken in some other nearby areas such as Otomah and Wesab.

Note 6. Watson's (1985) study might be the first to explore Raymi dialect. It is concerned with phonological aspects, not syntactic ones.

Note 7. An anonymous reviewer has pointed out that in Moroccan Arabic, there is a difference between the continuous and non-continuous forms. The first carries an extra meaning of contrastive focus with a correcting function, but not the second. The second is limited to negating a statement. Consider the following example he/she provides:

(i) $\mathrm{Al}$

$$
\text { ma-ši }
$$

mriD

yir Siyyan

Ali

NEG- NEG

sick

only tired

'Ali is not sick, he is only tired.'

However, this is not the case in Raymi dialect as mentioned above.

Note 8. It is worth mentioning that Vanhove's (1996) work does not provide any formal syntactic analysis but rather a syntactic and semantic description of the data.

Note 9. The Head Movement Constraint:

An $\mathrm{X}^{\circ}$ may only move into the $\mathrm{Y}^{\circ}$ that properly governs it (Travis, 1984, p. 131).

Note 10. In addition, Mansoor (2012, p. 34) pointed out that verbs in YA (Abyani dialect) do not merge with negation at all. The negative marker is always realised as a non-discontinuous element miš as shown below. 
(i) $\boldsymbol{m} \boldsymbol{i}$-š indina-hum as-siyarah haqqana

NEG- NEG gave.1.PL-them DEF-car ours

'We did not give them our car.'

Note 11. The cognate accusative/object is referred to in the Arabic literature as al-maffSuul al-muTlaq 'the absolute object,' which is defined as 'an accusative noun phrase that takes the form of its maSdar (nomina verbi or infinitives) or its substitute. It is used to emphasise the action of its governor (the verb or its substitutes), its kind or number" (Ar-raajihi, 1988, p. 277, cited in Homeidi, 2008, pp. 455-461). See also Ryding (2005, p. 285).

Note 12. Lucas (2010) considered the example in (44) above, discussing only the second possibility and ignoring the first.

Note 13. An anonymous reviewer has pointed out that this is possible if we stipulate that the phonetic realisation of $-\check{s}$ is done at PF, as suggested for the realisation of the partial verbal agreement in SA.

Note 14. In the context of oath, a special negation pattern is employed where the negative element $\check{s}$ is placed at the end of the clause. However, we will not discuss the analysis of this pattern because it needs further investigation to explore its syntactic and semantic features.

Note 15. Soltan (2014) points out in footnote 15 that "nothing hinges on the labels assigned to the two heads here" and that he follows Zanuttini (1997) "in assuming that negation is expressed via a polarity Phrase". Thus, it should be noted that the term 'polarity' does not refer to NPIs, but it simply refers to the affirmative-negative contrast (see e.g., Zeijlstra, 2004, 2008).

\section{Copyrights}

Copyright for this article is retained by the author, with first publication rights granted to the journal.

This is an open-access article distributed under the terms and conditions of the Creative Commons Attribution license (http://creativecommons.org/licenses/by/4.0/). 